\title{
Improving The Writing Skills Of Accounting Students: An Experiment
}

\author{
David Christensen, (Email: ChristensenD@ suu.edu), Southern Utah University \\ Jeff Barnes (Email: Barnes@ suu.edu), Southern Utah University \\ David Rees, (Email: Rees@suu.edu), Southern Utah University
}

\begin{abstract}
This paper reports the results a writing improvement initiative in an accounting department at a small western university. Numerous surveys of accounting professionals have established the importance of writing skills for accounting graduates, and challenge business schools to revise curricula accordingly. To determine if a writing initiative in an accounting department could improve the writing skills of accounting students, a series of one-page essays were given to students in four accounting classes during the fall semester. The essays were evaluated on six writing skills recently judged by accounting professionals to be most important for new hires to possess. Feedback was provided after each essay. Results showed that the writing skills improved significantly after each essay. Accounting students can improve their writing skills if the accounting faculty is committed to providing timely feedback.
\end{abstract}

\section{Introduction}

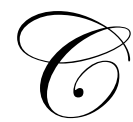

ommunication skills in writing, speaking, listening, and reading are critical competencies for any business professional. Of these, writing is clearly one of the most important skills for newly-hired accounting graduates to possess (Estes 1979, Gingras 1987, Deitrick and Tabor 1987, Siriram and Coppage 1992, Maupin and May 1993, Stevens and Stevens 1994, Christensen and Rees 2002, May and May 2003). In a recent national survey of accounting professionals to determine the relative importance of 32 business communication skills needed by newly-hired accounting graduates, seven of the top-ten skills were related to writing. The other three skills in the top-ten were "listens effectively," "asks appropriate questions to customers," and "asks appropriate questions to supervisors" (Table 1, Christensen and Rees 2002).

Surveys show that business schools have failed to adequately develop communication competencies, and challenge business schools to revise curricula accordingly (Siegel and Sorensen 1999, Albrecht and Sack 2000). Many accounting programs have responded to this challenge by adding communication assignments. A few studies have reported the positive impact of such assignments on the students' communication skills (Mohrweis 1991, Stout et al. 1991, Stocks et al. 1992, Garner 1994, Riordan et al. 2000, Ashbaugh et al. 2002). Using the skills in Table 1 as evaluation criteria, this paper reports the results of implementing a series short writing assignments in several accounting classes at a small university in the western United States. The following sections describe our methodology, results, and conclusions.

\section{Methodology}

To determine if accounting students could improve their communication skills in writing, we administered a series of one-page essays in four accounting classes during the fall semester of 2002. Three classes were undergraduate accounting courses (intermediate accounting, cost accounting, auditing), and one was a graduate course (advanced managerial accounting). Short essays were preferred over long essays to limit the amount of time required to grade the essays. In addition, according to survey research, short essays (e.g., business memoranda) more accurately reflect the kind of writing performed by new hires in accounting firms (DeLespinasse 1985, Hirsch and Collins 1988, Ashbaugh et al. 2002, Christensen and Rees 2002). 
The experiment was a "one group pretest-posttest design" (Stanley and Campbell 1966), where scores on the first essay were the pretest observation, and scores on the last essay were the posttest observation. Feedback from the instructor on each student's essay constituted the "treatment." ${ }^{11}$ Students were required to prepare the onepage essay on a word processor and return it the next time the class met. All essays were formatted the same (one page, double-spaced, 12-point Times New Roman font, 1-inch margins).

The first essay was assigned during the first week of the semester. Students were told that the essays would be graded on content and style, including grammar and spelling. Rather than having the same essay topic for all courses, each instructor chose to tailor the topic of the essay to the course. For example, in cost accounting and advanced management accounting, the assignment required students to identify one topic from the first chapter of their textbook, and summarize it in two paragraphs. In the first paragraph, each student summarized the topic. In the second paragraph, each student described how the topic could be applied to a specific business. In the other courses, students were assigned the same topic to write about. This policy was followed for the remaining essays.

Each essay was graded on the six writing skills shown in Table 2. The skills were derived from the survey reported by Christensen and Rees (2002). To measure skills one and five, the instructor identified the number of grammar and spelling errors on each essay. The remaining skills were subjectively scored by the instructor using a scale of 1 to 10, where 1 reflected many problems and 10 reflected no problems. Each instructor graded the essays from his own course and tried to grade each essay consistently.

Students received feedback on each essay in the form of the instructor's handwritten notes on the essay and the scores on the six skills. No class time was spent trying to teach writing skills. All of the students had completed a written communication course as part of the general education requirement at the university.

The expectation was that the writing skills of the accounting students would improve as they received feedback. To test this expectation, we computed the difference between the posttest and pretest scores for each student on each of the writing skills and then computed the mean difference, as indicted below:

Mean difference $=\Sigma($ Posttest score - Pretest score $) /$ Total number of students in experiment

The mean difference for each skill was tested using the paired t-test and the Wilcoxon signed rank test at an alpha of 0.05 (Sheskin 1996). ${ }^{2}$ For skills 2, 3, 4, and 6, a positive difference between the last essay and the first essay implied improvement. For example, if the scores on skill 2 were 7 for the first essay and 9 for the last essay, the difference of 2 implied improvement. The formal hypotheses and interpretation were as follows:

\begin{tabular}{lcc} 
Hypothesis & Measure & Interpretation \\
\hline Ho: & Mean difference $\leq 0$ & The writing skill did not improve significantly \\
Ha: & Mean difference $>0$ & The writing skill improved significantly
\end{tabular}

If Ho was rejected at an alpha of 0.05 , then the writing skill improved significantly.

For the skills 1 (grammar) and 5 (spelling), a negative difference implied improvement. For example, if the number of grammar errors were 7 on the first essay and 3 on the final essay, the difference between the last and first essay was -4 . The formal hypotheses and interpretation for skills 1 and 5 and the interpretation were as follows:

\footnotetext{
${ }^{1}$ The internal validity of our experiment was reduced by the absence of randomization and a control group. Our original intent was to include a control group in the experiment, where students would prepare an essay at the start and at the end of the course, with no feedback on their writing skills. However, we soon realized that many of the students in our control group were enrolled in one or more of the courses in our experiment, or the students had heard about the experiment from other students.

2 Although the paired-t test is generally reported to robust to minor violations of normality and equal variance, we chose to also use the nonparametric Wilcoxon test to strengthen our conclusions.
} 


\begin{tabular}{lcc} 
Hypothesis & Measure & Interpretation \\
\hline Ho: & Mean difference $\geq 0$ & The writing skill did not improve significantly \\
Ha: & Mean difference $<0$ & The writing skill improved significantly
\end{tabular}

If Ho was rejected at an alpha of 0.05 , then the writing skill improved significantly.

\section{Results}

The results of the hypotheses tests are presented in Table 3 . The mean differences for skills $2,3,4$, and 6 were highly significant $(\mathrm{p}<0.000)$, indicating that students were able to demonstrate improved abilities to write well (skill 2), organize information into effective sentences and paragraphs (skill 3), write persuasively (skill 4), and use an effective business vocabulary (skill 6). Similarly, the mean differences for skills 1 and 5 were highly significant $(\mathrm{p}<0.000)$, indicating that students improved their ability to write essays that were relatively free of grammar errors (skill 1) and spelling errors (skill 5).The results of the Wilcoxon test were consistent with the results of the paired-t test. $^{3}$

A post-test questionnaire was administered to students in the cost accounting and advanced management accounting classes. Using a five-point scale, students were asked to indicate the degree to which the essay assignments helped improve their abilities in each of the six writing skills. As shown in Table 4, the majority of the students felt that their writing skills improved. The students also indicated that the feedback received on the essays was effective in helping them improve their skills.

A statistical analysis of the scores on the second, third, and fourth essays indicated that, with only a few exceptions, the mean score for each skill improved significantly from one essay to the next essay. There was a slight decrease in performance on the last essay relative to the fourth essay, but the decrease was not statistically significant. We speculate that the decrease on the last essay was due to end-of-semester pressure.

Figure 1 illustrates the favorable trend in writing skills on the five essays. The largest improvement occurred after the feedback from the first essay. These results suggest that once the accounting students realized that their writing skills would be evaluated, the students had the capacity to generate superior essays. The results also suggest that the periodic feedback was effective in helping students improve their writing skills.

To determine if a student's ability to write superior essays would continue outside of our accounting classes, we collected and scored essays written by some of the accounting students in other classes at the end of the semester and compared the scores on these essays with the scores on the post-test essays from the four accounting classes. Students had no advance knowledge of the intended comparison, and wrote the essays according to the requirements of the other courses. We evaluated the first page of each of the essays using the same methods that we used in the accounting classes.

The results of this comparison are shown in Table 5 and Figure 2. The mean score on the post-test essays was not significantly different than the mean score on the essays prepared by the same students in the nonaccounting classes. ${ }^{4}$ These results suggest that the student's ability to write a superior essay continued in the other courses.

\section{Conclusion}

The writing skills of the accounting students in our one-semester experiment improved significantly as the students received regular feedback from their instructors. Because the essays were short, each instructor had enough time to evaluate each essay and provide meaningful feedback to each student during the semester. Significant

\footnotetext{
${ }^{3}$ Tables summarizing the results of the difference tests for each of the four accounting classes are available from the authors.

4 We found only 24 students in the other classes that were also in the accounting classes. Because we had no expectation of whether the scores in the non-accounting classes would be worse or better than the scores in the accounting classes, the hypothesis test was non-directional.
} 
improvement occurred from one essay to the next. We also found that the writing skills of our students did not deteriorate in other classes.

These results are consistent with the results of other writing-skill improvement initiatives (e.g., Riordan 2000, Ashbaugh et al. 2002), often described as "writing across the curriculum" and "writing within the discipline" (Britton et al. 1975). By writing about a topic within their discipline, students "learn to write" and "write to learn." The short writing assignments not only help students improve their writing skills, the process of writing can improve student comprehension of a topic because it forces the writer to retrieve, organize, and express the topic internally (Emig 1977, Odell 1980).

Some educators may reject the writing-within-the-discipline initiative because evaluating writing is "a job best left to English professors" (Munter 1999). We suggest that a writing assignment on an accounting topic cannot be adequately evaluated by non-accountants. In addition, employers of accounting graduates indicate that accounting students need as many writing opportunities before employment as they can get. Our results show that by assigning several short essays during the semester, accounting students can receive useful feedback on both their writing mechanics (e.g., spelling, grammar, punctuation) and their knowledge of the assigned accounting topic (e.g., writes well - clearly, concisely, correctly, completely).

Based on its review of undergraduate education, the Boyer Commission (1998:23) recommended that instructors pay more attention to writing skills:

Unfortunately, today's students too often think of composition as a boring English requirement rather than a life skill; ... Faculty too often think of composition as a task the English or composition department does badly, rather than understanding that an essential component of all faculty members' responsibility is making sure that their students have ample practice in both writing and speaking. In evaluating exams and papers, faculty members are often willing to forgive grammatical and stylistic blunders, thinking such matters the responsibility of composition teachers, as long as they believe they can grasp the essence of the student's text; that behavior reinforces the assumption on the part of students that clear communication is not important.

We support this recommendation.

\section{References}

1. Albrecht, W., and R. Sack. 2000. Accounting education: charting the course through a perilous future. Accounting Education Series 16. Sarasota, Florida: American Accounting Association.

2. Ashbaugh, H., K. Johnstone, and T. Warfield. 2002. Outcome assessment of a writing-skill improvement initiative:

3. Boyer Commission. 1998. Reinventing undergraduate education: a blueprint for America's research universities. http://notes.cc.sunysb.edu/Pres/boyer.nsf

4. Britton, J., T. Burgess, N. Martin, A. McLeod, and H. Rosen. 1975. The Development of Writing Abilities. London: Macmillian Education.

5. Christensen, D., and D. Rees. 2002. "An Analysis of the Business Communication Skills Needed by Entrylevel Accountants." Mountain Plains Journal of Business and Economics (Fall): 1-13.

6. Deitrick, J., and R. Tabor. 1987. Improving the writing skills of accounting majors: One school's approach. Advances in Accounting 4: 97-110.

7. DeLespinasse, D. 1985. Writing letters to clients: connecting textbook problems and the real world. Journal of Accounting Education 3:197-200.

8. Emig, J. 1977. Writing as a mode of learning. College Composition and Communication 28 (May):122128.

9. Estes, R. 1979. The profession's changing horizons: A survey of practitioners on the present and future importance of selected knowledge and skills. The International Journal of Accounting Education and Research (Spring):47-70. 
10. Garner, M. 1994. An efficient approach to writing across the curriculum: micro-themes in accounting classes. Journal of Education for Business 69 (Mar/Apr):211-216.

11. Gingras, R. 1987. Writing and the certified public accountant. Journal of Accounting Education 5:127-137.

12. Hirsch, M. and J. Collins. 1988. An integrated approach to communication skills in an accounting curriculum. Journal of Accounting Education 6:15-31.

13. Maupin, R. and C. May. 1993. Communication for accounting students. International Journal of Educational Management 7:30-38.

14. May, C. and G. May. 2003. Effective Writing: A Handbook for Accountants. Sixth edition. Upper Saddle River, NJ: Prentice Hall.

15. Mohrweis, L. 1991. The impact of writing assignments on accounting students' writing skills. Journal of Accounting Education 9:309-325.

16. Munter, Mary. 1999. Whacking wac. Business Communication Quarterly 62 (March):108-111.

17. Odell, L. 1980. The process of writing and the process of learning. College Composition and Communication 31 (February):42-50.

18. Riordan, D., M. Riordan, and M. Sullivan. 2000. Writing across the accounting curriculum: an experiment. Business Communication Quarterly 63 (Sep):49-59.

19. Sheshkin, D. 1996. Handbook of parametric and nonparametric statistical procedures. New York: CRC Press.

20. Siegel, G., and J. Sorensen. 1994. What corporate America wants in entry-level accountants. Journal of Accountancy (August).

21. Siegel, G. 2000. Management accountants: the great communicators. Strategic Finance (December): 75-76.

22. Siriram, R. and R. Coppage. 1992. A comparison of educators' and CPA practitioners' views on communication training in the accounting curriculum. Journal of Applied Business Research (Summer): 111.

23. Stocks, K., T. Stoddard, and M. Waters. 1992. Writing in the accounting curriculum: Guidelines for professors. Issues in Accounting Education 7:193-204.

24. Stout, D. A. Sumutka, and D. Wygal. 1991. Experiential evidence of the use of writing assignments in upper-level accounting courses. Advances in Accounting 9:125-141.

25. Stanely, D. and J. Campbell. 1966. Experimental and Quasi-experimental Designs for Research. Chicago: Rand McNally College Publishing Company.

26. Stevens, K. and W. Stevens. 1994. Can your new auditors communicate? The Internal Auditor (April):3738 .

Table 1: Top-Ten Communication Skills Needed By Accounting Graduates

\begin{tabular}{cl}
\hline Importance & Communication Skill \\
\hline 1 & Listens effectively \\
2 & Uses correct grammar in both spoken and written communication \\
3 & Writes well - clearly, concisely, correctly, completely \\
4 & Produces correctly spelled documents \\
5 & Asks appropriate questions when talking with customers \\
6 & Organizes information into effective sentences and paragraphs \\
7 & Uses an effective business vocabulary \\
8 & Punctuates documents properly \\
9 & Asks appropriate questions when talking with supervisors \\
10 & Edits and revises documents conscientiously \\
\hline
\end{tabular}


Table 2: Writing Skills Evaluated

\begin{tabular}{lll}
\hline & Writing skill & Measurement \\
\hline 1 & Uses correct grammar (including punctuation) & Number of errors \\
2 & Writes well - clearly, concisely, correctly, completely & 1 to 10 \\
3 & Organizes information into effective sentences and paragraphs & 1 to 10 \\
4 & Writes persuasively & 1 to 10 \\
5 & Produces correctly spelled documents & Number of errors \\
6 & Uses an effective business vocabulary & 1 to 10 \\
\hline
\end{tabular}

Table 3: Results Of Difference Tests (All Classes)

\begin{tabular}{|l|c|c|c|c|c|c|c|c|c|c|c|}
\hline & & \multicolumn{2}{|c|}{ Posttest } & \multicolumn{2}{c|}{ Pretest } & \multicolumn{2}{c|}{ Difference } & \multicolumn{2}{c|}{ Paired-T Test } & \multicolumn{2}{c|}{ Wilcoxon Test } \\
\hline Skill & $\mathrm{N}$ & Mean & Std dev & Mean & Std dev & Mean & Std dev & $\mathrm{T}$ & $\begin{array}{l}\text { Signif } \\
\text { icance }\end{array}$ & $\begin{array}{l}\text { Z } \\
\text { Signif- } \\
\text { icance }\end{array}$ \\
\hline Grammar & 73 & 0.658 & 0.786 & 2.932 & 2.854 & -2.274 & 2.883 & -6.739 & 0.000 & -6.104 & 0.000 \\
\hline Writes well & 73 & 9.192 & 1.243 & 6.274 & 1.924 & 2.918 & 2.087 & 11.947 & 0.000 & -6.950 & 0.000 \\
\hline Organization & 73 & 9.534 & 1.015 & 6.975 & 1.641 & 2.740 & 1.788 & 13.095 & 0.000 & -6.935 & 0.000 \\
\hline Persuasive & 73 & 9.493 & 1.015 & 6.767 & 1.679 & 2.726 & 1.766 & 13.190 & 0.000 & -7.006 & 0.000 \\
\hline Spelling & 73 & 0.479 & 0.689 & 1.904 & 2.376 & -1.425 & 2.380 & -5.114 & 0.000 & -4.917 & 0.000 \\
\hline Effective Vocabulary & 73 & 9.507 & 1.002 & 6.918 & 1.320 & 2.589 & 1.562 & 14.162 & 0.000 & -7.012 & 0.000 \\
\hline
\end{tabular}

Table 4: Results Of Post-Test Questionnaire

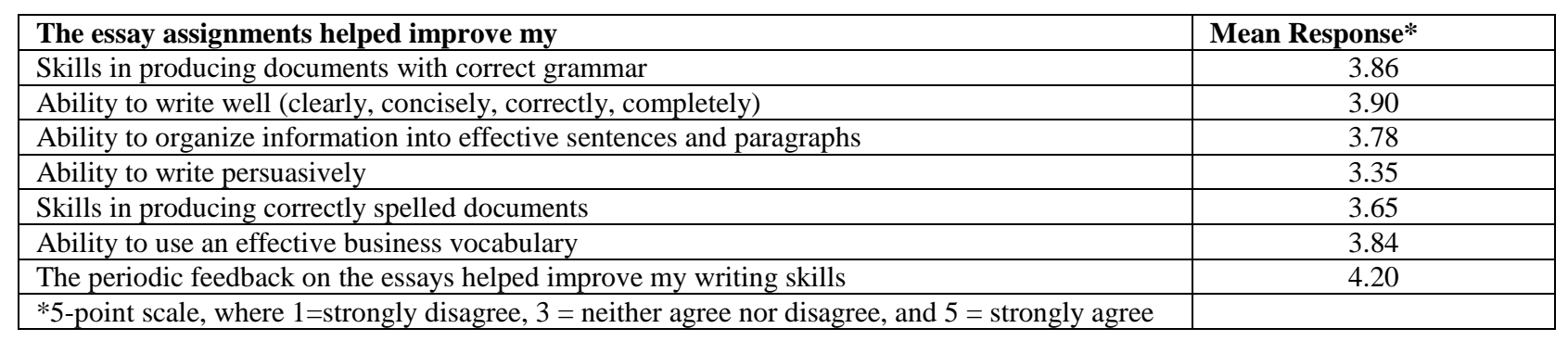

Table 5: A Comparison Of Final Essay Scores In Accounting Classes With Essay Scores In Non-Accounting Classes

\begin{tabular}{|c|c|c|c|c|c|c|c|c|c|c|c|}
\hline \multirow[b]{2}{*}{ Skill } & \multirow[b]{2}{*}{$\mathrm{N}$} & \multicolumn{2}{|c|}{$\begin{array}{c}\text { Essay5 } \\
\text { (Accounting) }\end{array}$} & \multicolumn{2}{|c|}{$\begin{array}{l}\text { Essay (Non- } \\
\text { accounting) }\end{array}$} & \multicolumn{2}{|c|}{ Difference } & \multicolumn{2}{|c|}{ Paired-T Test } & \multicolumn{2}{|c|}{ Wilcoxon Test } \\
\hline & & Mean & $\begin{array}{l}\text { Std } \\
\text { dev }\end{array}$ & Mean & Std dev & Mean & Std dev & $\mathrm{T}$ & $\begin{array}{l}\text { Signif- } \\
\text { icance }\end{array}$ & $\mathrm{Z}$ & $\begin{array}{l}\text { Signif- } \\
\text { icance }\end{array}$ \\
\hline Grammar & 24 & 0.708 & 0.751 & 1.125 & 1.191 & -0.417 & 1.060 & -1.926 & 0.067 & -1.821 & 0.069 \\
\hline Writes well & 24 & 8.583 & 1.742 & 9.042 & 1.042 & -0.459 & 1.503 & -1.494 & 0.149 & -1.436 & 0.151 \\
\hline Organization & 24 & 9.167 & 1.494 & 9.208 & 1.103 & -0.041 & 1.197 & 0.171 & 0.866 & -0.183 & 0.855 \\
\hline Persuasive & 24 & 9.125 & 1.393 & 9.333 & 0.917 & -0.208 & 0.932 & -1.096 & 0.285 & -1.026 & 0.305 \\
\hline Spelling & 24 & 0.625 & 0.824 & 0.708 & 0.999 & -0.083 & 1.248 & -0.327 & 0.747 & -0.060 & -.052 \\
\hline \begin{tabular}{|l|} 
Effective \\
Vocabulary
\end{tabular} & 24 & 9.250 & 1.359 & 9.542 & 0.277 & -0.292 & 0.999 & -1.430 & 0.166 & -1.393 & 0.163 \\
\hline
\end{tabular}



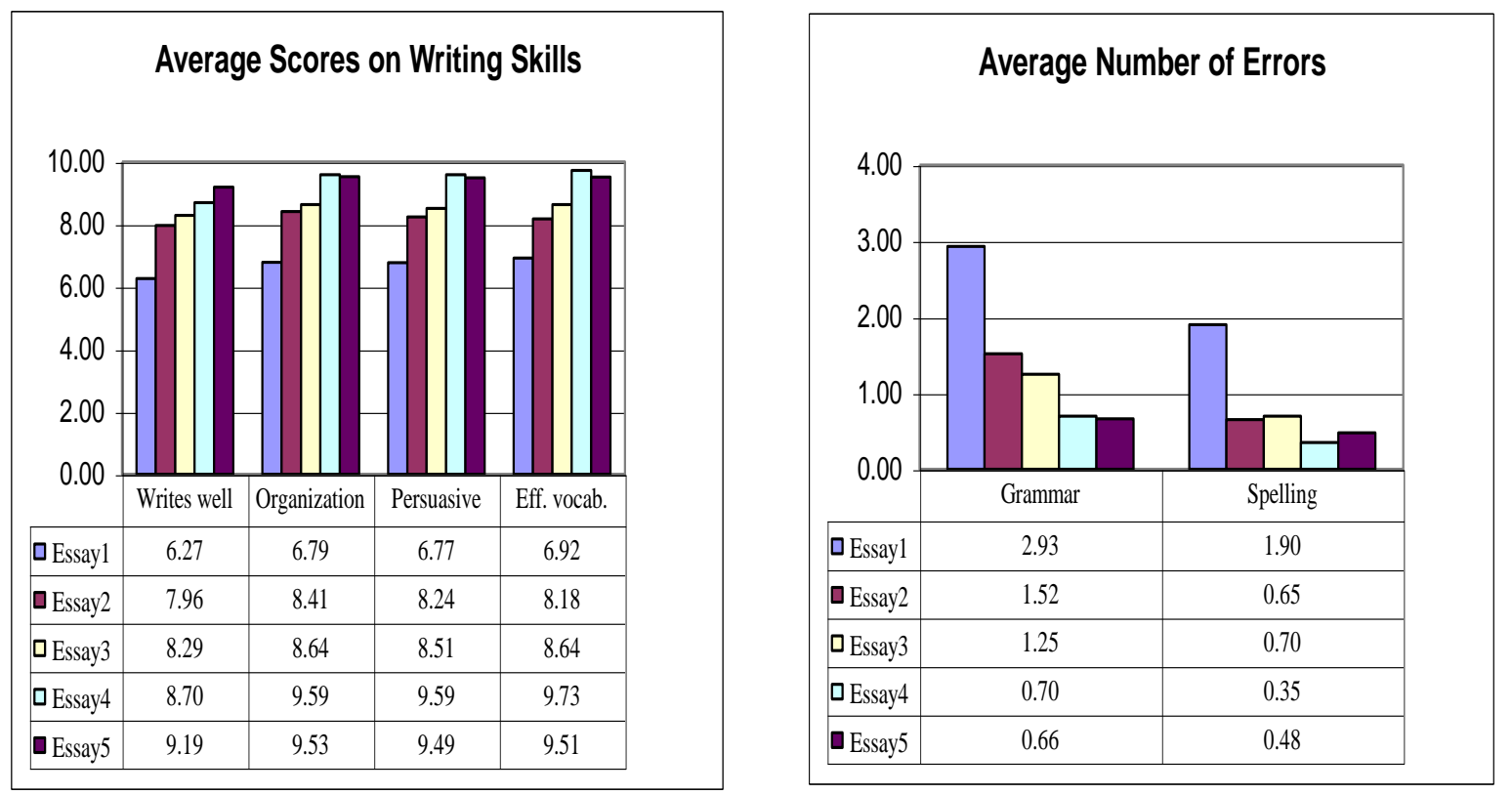

Figure 1. Average Scores on Writing Skills and Grammar/Spelling Errors
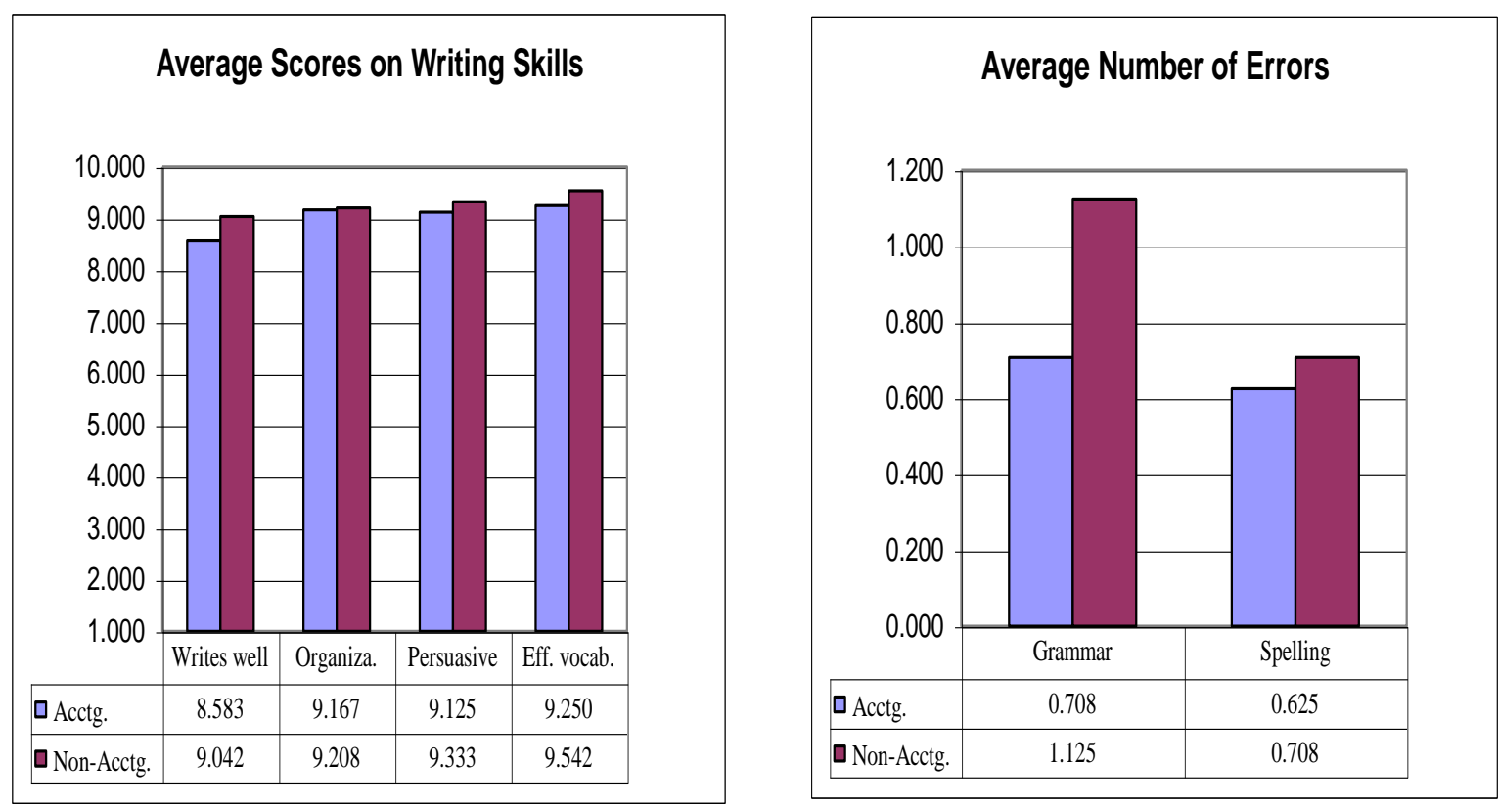

Figure 2. Average Scores on Writing Skills and Grammar/Spelling Errors from Last Accounting and Non-accounting Essays 
Notes 